\title{
SOMATIC CELL HETEROGENEITY BETWEEN DNA EXTRACTED FROM LYMPHOCYTES AND SKELETAL MUSCLE IN CONGENITAL MYOTONIC DYSTROPHY
}

\author{
Kazuhiro OHYa, ${ }^{1, *}$ Nobutada TACHI, ${ }^{1}$ Shin-ichiro Kon, ${ }^{2}$ \\ Kokichi KIKUCHI, ${ }^{2}$ and Shunzo CHIBA ${ }^{1}$ \\ ${ }^{1}$ Department of Pediatrics and ${ }^{2}$ Department of Pathology (Section 1), \\ Sapporo Medical University School of Medicine, \\ South-1 West-16, Chuo-ku, Sapporo 060, Japan
}

\begin{abstract}
Summary Myotonic dystrophy (DM) results from the expansion of an unstable CTG trinucleotide repeat in the $3^{\prime}$ untranslated region of mRNA encoding a putative serine/threonine protein kinase. The degree of the CTG repeat amplification in genomic DNAs extracted from lymphocytes correlates with disease severity. We have analyzed the amplification of the CTG repeat of DNAs extracted from skeletal muscles and lymphocytes in five congenital DM patients. The amplification from skeletal muscles showed an increase of about $1.5 \mathrm{~kb}$ to $3.5 \mathrm{~kb}$ larger than that from lymphocytes in all patients. Furthermore, we have investigated the somatic instability of the CTG repeat in various tissues from a severe congenital DM patient.

Key Words myotonic dystrophy (DM), congenital form, unstable trinucleotide (CTG) repeat somatic cell heterogeneity
\end{abstract}

\section{INTRODUCTION}

Myotonic dystrophy (DM) is an autosomal dominant, multisystemic disorder characterized by myotonia, progressive muscle weakness and atrophy, cardiac conduction disturbances and cataracts (Harper, 1989). DM shows marked variability in its expression, ranging from severe congenital forms to an asymptomatic form. The rare congenital form of DM is associated with severe hypotonia, feeding difficulty, neonatal respiratory distress, motor developmental delay, and mental retardation. Höweler et al. (1989) reported that transmission of congenital DM is exclusively maternal. Patient's mothers frequently have mild to subclinical manifestations of DM. Ashizawa et al. (1993a) observed anticipation, successively

Received July 25, 1995; Revised version accepted September 26, 1995.

* To whom correspondence should be addressed. 
earlier age at onset and increasing severity of the disease in successive generations in the pedigree of a DM family. However, we have found genetic evidence confirming the original hypothesis of paternal origin of congenital DM, and have suggested an explanation for the phenomenon of anticipation (Ohya et al., 1994).

The molecular basis of DM mutation is an unstable trinucleotide (CTG) repeat, located in the $3^{\prime}$ end of a transcript encoding a putative serine/threonine protein kinase gene of chromosome 19q13.3 (Brook et al., 1992; Mahadevan et al., 1992; Fu et al., 1992). Trinucleotide repeat mutation similar to DM have been identified in Fragile X mental retardation syndrome (Verkerk et al., 1991), spinal and bulbar muscular atrophy (Kennedy's disease) (La Spada et al., 1991), FRAXE mental retardation (Knight et al., 1993), Huntington's disease (The Huntington's disease collaborative research group, 1993), spinocerebellar ataxia type 1 (Orr et al., 1993), dentatorubral-pallidoluysian atrophy (Nagafuchi et al., 1994), and Machado-Joseph disease (Kawaguchi et al., 1994).

The disease severity in DM generally correlates to the size of the expanded CTG repeats in lymphocytes from patients with DM, but the mechanism of this is unclear. In adult DM patients, the expansion of the repeat isolated from skeletal muscle is larger than that in lymphocytes from the same patients. In this paper we described a comparison of the CTG repeat amplification of genomic DNAs from lymphocytes and skeletal muscles in five unrelated cases of congenital DM patients, based on Southern blot analysis using the probe p5B1.4 (Shelbourne et al., 1992) derived from cDNA25 (Buxton et al., 1992). Furthermore, we have examined the genomic DNAs of various tissues in a severely affected neonate with congenital DM and demonstrated somatic cell heterogeneity in the organ tissues of congenital DM.

\section{MATERIALS AND METHODS}

Materials. We studied five patients with congenital DM whose mother had been diagnosed with adult DM. These congenital patients had characteristic clinical features such as marked hypotonia with facial weakness, respiratory distress, and feeding difficulty during the neonatal period. In addition to the typical clinical manifestations of congenital DM, muscle histopathology was consistent with congenital DM. Table 1 summarizes the characteristics of the patients.

Peripheral blood lymphocytes from the patients were taken at the time of this study, but the muscle samples had been taken 1 to 8 years earlier, frozen in liquid nitrogen and stored at $-80^{\circ} \mathrm{C}$ until the analyses reported here. All muscle samples were taken from the quadriceps femoral muscle. We obtained. seven kinds of postmortem tissues, including liver, diaphragm, urinary bladder, small intestine, tongue, uterus, and cerebral cortex, from a severely affected neonate with congenital DM, who died of respiratory failure at one month of age.

Southern blot analysis. Genomic DNAs were prepared from peripheral-blood 
Table 1. Summary of clinical features in five patients with congenital DM.

\begin{tabular}{lccccc}
\hline Case & 1 & 2 & 3 & 4 & 5 \\
\hline Age (years) & 2 & 17 & 3 & 3 & 5 \\
Age diagnosed with congenital DM & 1 month & 9 years & 2 years & 2 years & 1 month \\
Sex & F & F & $F$ & $F$ & M \\
Gestational age (weeks) & 35 & 40 & 38 & 39 & 38 \\
Weight at birth (g) & 2,238 & 3,450 & 3,198 & 2,538 & 2,720 \\
Polyhydramnios & + & - & - & - & - \\
Asphyxia & + & + & + & + & + \\
Neonatal respiratory distress & + & + & + & + & + \\
Period for mechanical ventilation & 30 days & - & - & - & 10 days \\
Feeding difficulty & + & + & + & + & + \\
Floppiness in neonatal period & + & + & + & + & + \\
Facial weakness & + & + & + & + & + \\
Mental retardation & + & + & + & + & + \\
Myotonia & - & + & - & - & + \\
Muscle weakness & + & + & + & + & + \\
Origin of DM gene & mother & mother & mother & mother & mother \\
Biopsied and diagnosed age & month & 9 years & 2 years & 2 years & 1 month \\
\hline
\end{tabular}

lymphocytes and biopsied skeletal muscle from the five patients by standard procedures (Sambrook et al., 1989). Genomic DNAs were digested with the restriction endonucleases EcoRI and $B g / \mathrm{I}$, separated by electrophoresis on $0.8 \%$ agarose gel, and transferred onto nylon membranes using a vacuum transfer apparatus. After prehybridization, digested DNAs were hybridized to radiolabeled p5B1.4 for 24 $\mathrm{hr}$. The filters were washed to a stringency of $0.1 \times \mathrm{SSC}$ containing $0.1 \% \mathrm{SDS}$ and autoradiography was performed for 2 to 5 days at $-80^{\circ} \mathrm{C}$. The probe p5B1.4, which was supplied by Dr. Keith Johnson, is a $1.4 \mathrm{~kb}$ BamHI fragment from cDNA25 subcloned into pBluescript $\mathrm{SK}+$; it was labeled by random priming.

$P C R$ amplification method. In determining the precise number of CTG repeat of normal allele, polymerase chain reaction (PCR) amplification was carried out using CTG region flanking primers 406 and 409 reported by Mahadevan et al. (1992). PCR cycling conditions were as follows: initial denaturation at $95^{\circ} \mathrm{C}$ for $3 \mathrm{~min}$, then 35 cycles of $95^{\circ} \mathrm{C}$ for $1.5 \mathrm{~min}, 65^{\circ} \mathrm{C}$ for $1 \mathrm{~min}, 72^{\circ} \mathrm{C}$ for $2 \mathrm{~min}$, and $72^{\circ} \mathrm{C}$ for $7 \mathrm{~min}$.

\section{RESULTS}

Southern blot analysis using EcoRI-digested DNAs probed with p5B1.4 showed an EcoRI polymorphism with alleles of $9.8 \mathrm{~kb}$ and $8.6 \mathrm{~kb}$ in normal populations 
(Fig. 1). Patient 1 had alleles of $8.6 \mathrm{~kb} / 15.0 \mathrm{~kb}$ (about $1,700 \mathrm{CTG}$ repeats) in lymphocytes and $8.6 \mathrm{~kb} / 16.5 \mathrm{~kb}$ (about 2,200 CTG repeats) in skeletal muscle. Patient 3 had alleles of $8.6 \mathrm{~kb} / 15.5 \mathrm{~kb}$ (about 1,900 CTG repeats) in lymphocytes and $8.6 \mathrm{~kb} / 17.5 \mathrm{~kb}$ (about 2,500 CTG repeats) in skeletal muscle. Patient 4 had alleles of $8.6 \mathrm{~kb} / 14.0 \mathrm{~kb}$ (about 1,400 CTG repeats) in lymphocytes and $8.6 \mathrm{~kb} /$ $17.5 \mathrm{~kb}$ (about 2,500 CTG repeats) in skeletal muscle. Patient 5 had alleles of $9.8 \mathrm{~kb} / 14.0 \mathrm{~kb}$ (about 1,400 CTG repeats) in lymphocytes and $9.8 \mathrm{~kb} / 15.5 \mathrm{~kb}$ (about 1,900 CTG repeats) in skeletal muscle. Patients $1,3,4$, and 5 had larger expanded bands, ranging from $1.5 \mathrm{~kb}$ to $3.5 \mathrm{~kb}$, in skeletal muscle than in lymphocytes.

Southern blot analysis using BglI-digested DNAs probed with p5B1.4 shows a single band of $3.4 \mathrm{~kb}$ in normal populations. In Bgll-digested fragments (Fig. 2), patients $1,2,3$, and 4 had additional expanding bands ranging from $4.0 \mathrm{~kb}$ to $5.5 \mathrm{~kb}$ in lymphocytes and $5.5 \mathrm{~kb}$ to $7.5 \mathrm{~kb}$ in skeletal muscle. All five patients had a larger expanded band, ranging from $1.5 \mathrm{~kb}$ to $3.5 \mathrm{~kb}$, in skeletal muscle than in lymphocytes, which suggested that the somatic cell heterogeneity between skeletal muscle and lymphocytes was established during the early stage of childhood.

A patient with severe congenital DM had an abnormal enlarged and blurred band of $12.4 \mathrm{~kb}$ which demonstrated slight somatic cell heterogeneity in different organs. The tissues also showed similarity in numbers of CTG repeats (Fig. 3).

The number of CTG repeats of normal allele in lymphocytes and skeletal

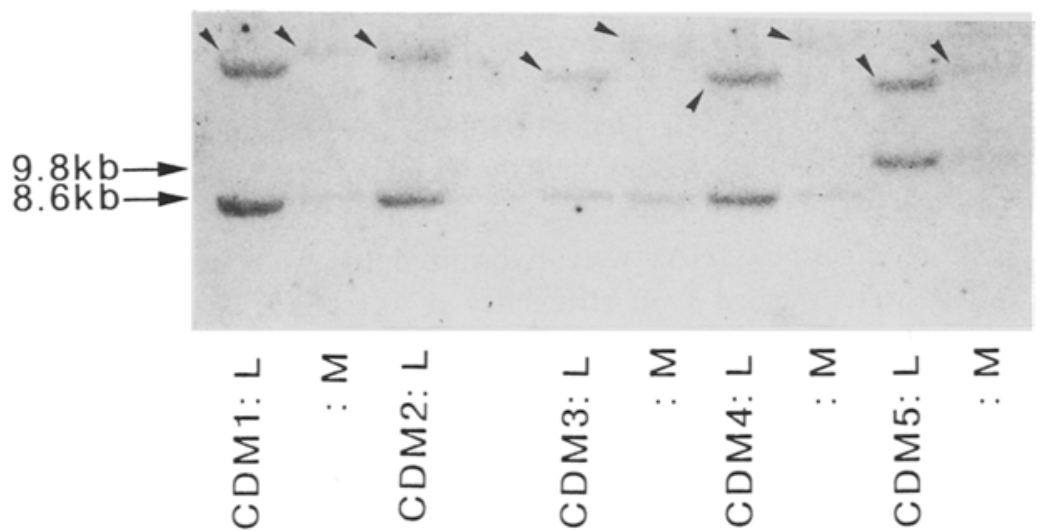

Fig. 1. The expansion of the CTG repeat in EcoRI fragments from lymphocytes (L) and skeletal muscles (M) in four patients with congenital myotonic dystrophy (CDM). Southern blot analysis using EcoRI fragments probed with p5B1.4 showed an EcoRI polymorphism with alleles of $9.8 \mathrm{~kb}$ and $8.6 \mathrm{~kb}$ in normal populations. Sites of alleles in lymphocytes and skeletal muscle were as follows: Patient 1: $8.6 \mathrm{~kb} / 15.0 \mathrm{~kb}$ (L), $8.6 \mathrm{~kb} / 16.5 \mathrm{~kb}(\mathrm{M})$, Patient $3: 8.6 \mathrm{~kb} / 15.5 \mathrm{~kb}(\mathrm{~L}), 8.6$ $\mathrm{kb} / 17.5 \mathrm{~kb}(\mathrm{M})$; Patient 4: $8.6 \mathrm{~kb} / 14.0 \mathrm{~kb}(\mathrm{~L}), 8.6 \mathrm{~kb} / 17.5 \mathrm{~kb}(\mathrm{M})$; Patient 5: $9.8 \mathrm{~kb} / 14.0 \mathrm{~kb}(\mathrm{~L}), 9.8 \mathrm{~kb} / 15.5 \mathrm{~kb}(\mathrm{M})$. Patients $1,3,4$, and 5 had a larger expanded band (arrowheads), ranging from $1.5 \mathrm{~kb}$ to $3.5 \mathrm{~kb}$, in skeletal muscle than in lymphocytes. 


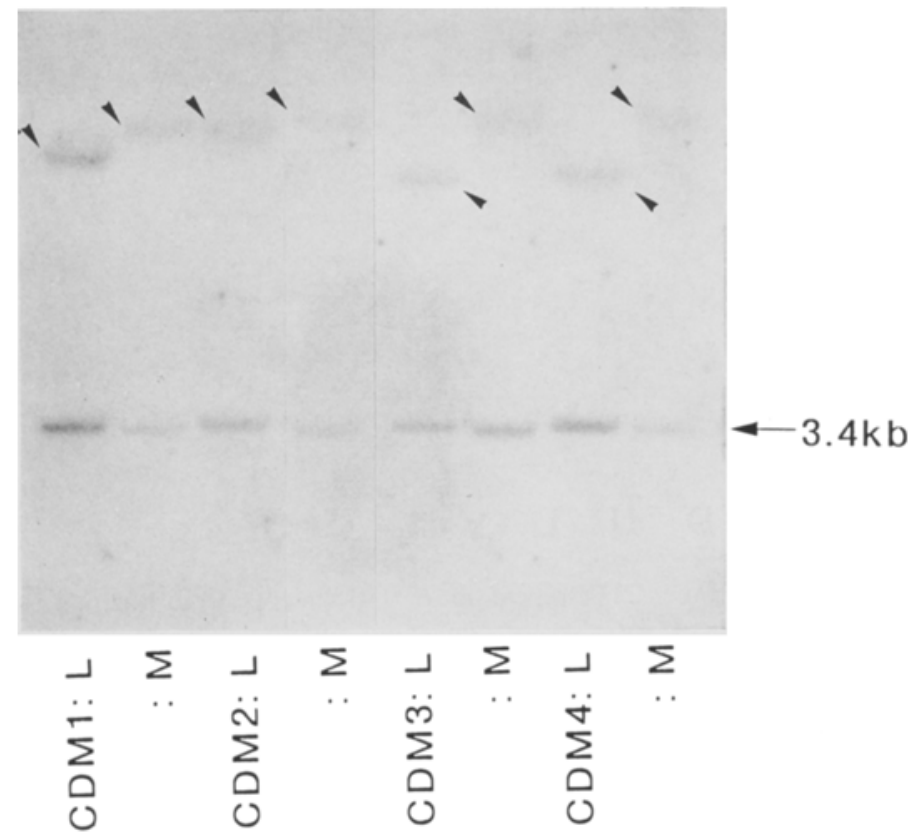

Fig. 2. The expansion of the CTG repeat in BglI fragments from lymphocytes (L) and skeletal muscles (M) in four patients with congenital myotonic dystrophy (CDM). Southern blot analysis using $B g / l$ fragments probed with p5B1.4 showed a single band of $3.4 \mathrm{~kb}$ in normal populations. Sites of alleles in lymphocytes and skeletal muscle were as follows: Patient 1: $3.4 \mathrm{~kb} / 8.5 \mathrm{~kb}(\mathrm{~L}), 3.4 \mathrm{~kb} / 10.0$ $\mathrm{kb}(\mathrm{M})$; Patient 2: $3.4 \mathrm{~kb} / 9.0 \mathrm{~kb}(\mathrm{~L}), 3.4 \mathrm{~kb} / 11.0 \mathrm{~kb}(\mathrm{M})$; Patient 3: $3.4 \mathrm{~kb} / 7.5$ $\mathrm{kb}(\mathrm{L}), 3.4 \mathrm{~kb} / 11.0 \mathrm{~kb}(\mathrm{M})$; Patient $4: 3.4 \mathrm{~kb} / 7.5 \mathrm{~kb}(\mathrm{~L}), 3.4 \mathrm{~kb} / 11.0 \mathrm{~kb}(\mathrm{M})$. Patients $1,2,3$, and 4 had a larger expanded band (arrowheads), ranging from 1.5 $\mathrm{kb}$ to $3.5 \mathrm{~kb}$, in skeletal muscle than in lymphocytes.

muscle was identical by PCR analysis (data not shown).

\section{DISCUSSION}

Myotonic dystrophy (DM) is quite variable in phenotype, ranging from a severe congenital form that is frequently fatal soon after birth to a complete $a b$ sence of symptoms. The clinical manifestations of congenital DM are quite distinct from these of the adult form. The genetic mutation underlying DM is an unstable trinucleotide (CTG) repeat, recently located in the $3^{\prime}$ end of a transcript encoding a putative serine/threonine protein kinase gene (Brook et al., 1992; Mahadevan et al., 1992; Fu et al., 1992). Since then Fu et al. have also found that patients with adult DM have decreased levels of messenger RNA (mRNA) and protein expression (Fu et al., 1993). Alternative spliced forms of mRNAs have been identi- 


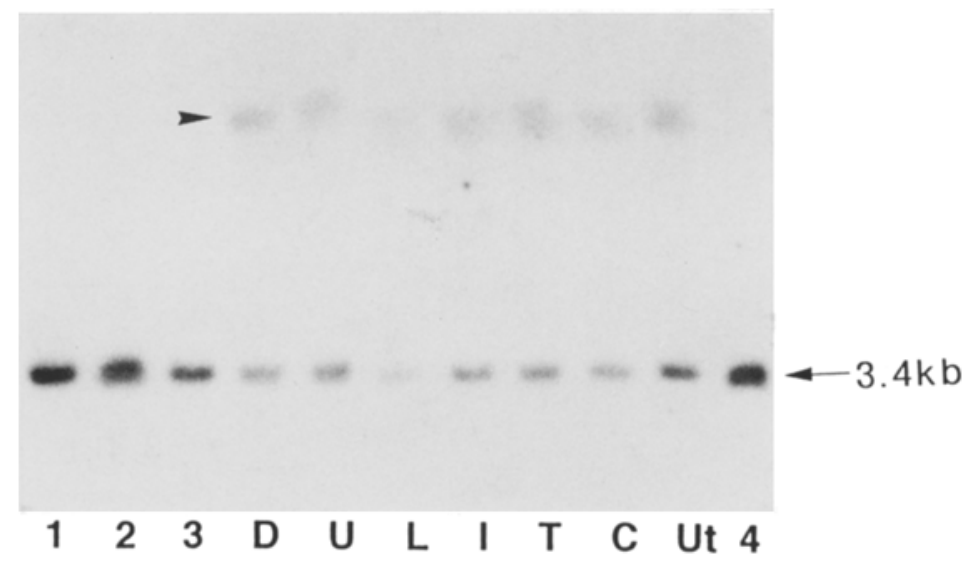

Fig. 3. The expansion of the CTG repeat in $B g l$ fragments from various tissues in an autopsied patient with severe congenital myotonic dystrophy (CDM). 1, skeletal muscle; 2, cardiac muscle; 3 , liver; L, liver; D, diaphragm; U, urinary bladder; I, small intestine; $T$, tongue; Ut, uterus; $C$, cerebral cortex; 4 , lymphocyte. $1,2,3,4$ : normal individuals. The patient with severe congenital DM had an abnormal enlarged and blurred band (an arrowhead) of $12.4 \mathrm{~kb}$. See text for correctionary.

fied in various tissues of DM (Jansen et al., 1992; Fu et al., 1993), suggesting that the product of the gene as it is expressed in different tissues could influence the clinical features of DM. Although the molecular analyses of DM has developed rapidly, the mechanism of DM gene function is still unknown.

The disease severity of congenital DM generally seems to correspond to the length of CTG repeat amplification in mutant genes from lymphocytes, but this correlation is weaker in the alleles of other organs such as skeletal muscle. Anvret et al. (1993) were the first to report that the expansions of CTG repeat in muscle from patients with adult form of DM were much larger than those in lymphocytes. They demonstrated that the expansions seen in muscle from adult DM were stable over a significant time period (10-15 years) and were useful to predict the progression of DM symptoms. Thornton et al. (1994) reported that the DM-specific expansive alleles in skeletal muscle from adult DM were 2- to 13-fold the size of those in lymphocytes; different muscles were generally consistent with each other within each patient. Ashizawa et al. (1993b) also reported move expanded CTG repeat in skeletal muscle from adult DM patients than lymphocytes.

Thornton et al. and Ashizawa et al. demonstrated that the size of CTG repeat amplifications in affected tissues, such as skeletal muscle, correlated better with DM severity than the repeat in lymphocytes did. They concluded that the somatic instability of the repeat might cause substantial somatic cell heterogeneity. Mahadevan et al. (1992) suggested that a blurred or smeared appearance of expanded alleles seen in Southern blots in lymphocytes indicated somatic cell heterogeneity 
in the size of the expanded alleles. Lavedan et al. (1993) reported that, as observed in lymphocytes, various tissues of a 20 -wk-old fetus carrying the DM mutation showed discrepancy in the size of expanded CTG repeat under Southern blot analysis, reflecting the mitotic instability in all fetal tissues.

Our data are also consistent with the results of Thornton et al. and Ashizawa et al., and demonstrate that the extent of the expanded CTG repeat in skeletal muscle from congenital DM patients was always larger than that of in lymphocytes. It is likely that somatic cell heterogeneity is established during the early stage of childhood. Furthermore, we displayed somatic cell heterogeneity within different organs except for lymphocytes from the same congenital DM patient, and minimal degree disparity among the expansions of CTG repeats of various tissues. The mechanism of the DM gene is still unknown. A next topic is to analyze the DM kinase gene on the mRNA and protein level.

Acknowledgment We are grateful to Dr. Keith Johnson (Department of Anatomy, Charing Cross and Westminster Medical School, UK) for providing the probe p5B1.4.

\section{REFERENCES}

Anvret M, Åhlberg G, Grandell U, Hedberg B, Johnson K, Edström L (1993): Larger expansions of the CTG repeat in the muscle compared to lymphocytes from patients with myotonic dystrophy. Hum Mol Genet 2: 1397-1400

Ashizawa T, Dubel JR, Dunne PW, Dunne CJ, Fu Y-H, Pizzuti A, Caskey CT, Boerwinkle E, Perryman MB, Epstein HF, Hejtmancik JF (1993a): Anticipation in myotonic dystrophy. II. Complex relationship between clinical findings and structure of the GCT repeat. Neurology 42: $1877-1883$

Ashizawa T, Dubel JR, Harati Y (1993b): Somatic instability of CTG repeat in myotonic dystrophy. Neurology 43: 2674-2678

Brook JD, McCurrach ME, Harley HG, Buckler AJ, Church D, Aburatani H, Hunter K, Stanton VP, Thirion J-P, Hudson T, Sohn R. Zemelman B, Snell RG, Rundle SA, Crow S, Davies J, Shelbourne P, Buxton J, Jones C, Juvonen V, Johnson K, Harper PS, Shaw DJ, Housman DE (1992): Molecular basis of myotonic dystrophy: expansion of a trinucleotide (CTG) repeat at the $3^{\prime}$ end of a transcript encoding a protein kinase family member. Cell 68: 799-808

Buxton J, Shelbourne P, Davies J, Jones C, Van Tongeren T, Aslanidis C, de Jong P, Jansen G, Anvret M, Riley B, Williamson R, Johnson K (1992): Detection of an unstable fragment of DNA specific to individuals with myotonic dystrophy. Nature 355: 547-548

Fu Y-H, Pizzuti A, Fenwick RG Jr, King J, Rajnarayan S, Dunne PW, Dubel J, Nasser GA, Ashizawa T, de Jong P, Wieringa B, Korneluk R, Perryman MB, Epstein HF, Caskey CT (1992): An unstable triplet repeat in a gene related to myotonic muscular dystrophy. Science 255 : $1256-1258$

Fu Y-H, Friedman DL, Richards S, Pearlman JA, Gibbs RA, Pizzuti A, Ashizawa T, Perryman MB, Scarlato G, Fenwick RG Jr, Caskey CT (1993): Decreased expression of myotonin-protein kinase messenger RNA and protein in adult form of myotonic dystrophy. Science 260: 235238

Harper PS (1989): Myotonic Dystrophy. 2nd ed. W.B. Saunders, Philadelphia, PA

Höweler CJ, Busch HFM, Geraedts JPM, Niermeijer MF, Staal A (1989): Anticipation in myotonic dystrophy: fact or fiction. Brain 112: 779-797

Jansen G, Mahadevan M, Amemiya C, Wormskamp N, Segers B, Hendriks W, O'Hoy K, Baird S, 
Sabourin L, Lennon G, Jap PL, Iles D, Coerwinkel M, Hofker M, Carrano AV, de Jong PJ, Korneluk RG, Wieringa B (1992): Characterization of the myotonic dystrophy region predicts multiple protein isoform-encoding mRNAs. Nature Genet 1: 261-266

Kawaguchi Y, Okamoto T, Taniwaki M, Aizawa M, Inoue M, Katayama S, Kawakami H, Nakamura S, Nishimura M, Akiguchi I, Kimura J, Narumiya S, Kakizuki A (1994): CAG expansion in a novel for Machado Joseph disease chromosome 14q32.1. Nature Genet 8: 221-228

Knight SIL, Flannery AV, Hirst MC, Campbell L, Christodoulou Z, Rhelps SR, Pointon J, Middleton-Price HR, Barnicoat A, Pembrey ME, Holland J, Oostra BA, Bobrow M, Davies KE (1993): Trinucleotide repeat amplification and hypermethylation of a CpG island in FRAXE mental retardation. Cell 74: 127-134

La Spada AR, Wilson EM, Lubahn DB, Harding AE, Fischbeck KH (1991): Androgen receptor gene mutations in X-linked spinal and bulbar muscular dystrophy. Nature 352: 77-79

Lavedan C, Hofmann-Radvanyi H, Shelbourne P, Rabes J-P, Duros C, Savoy D, Dehaupas I, Luce S, Johnson K, Junien C (1993): Myotonic dystrophy: size- and sex-dependent dynamics of CTG meiotic instability, and somatic mosaicism. Am J Hum Genet 52: 875-883

Mahadevan M, Tsilfidis C, Sabourin L, Shutler G, Amemiya C, Jansen G, Neville C, Narang M, Barceló J, O'Hoy K, Leblond S, Earle-Macdonald J, de Jong PJ, Wieringa B, Korneluk RG (1992): Myotonic dystrophy: an unstable CTG repeat in the $3^{\prime}$ untranslated region of the gene. Science 255: 1253-1255

Nagafuchi S, Yanagisawa H, Sato K, Shirayama T, Ohsaki E, Bundo M, Takeda T, Tadokoro K, Kondo I, Murayama N, Tanaka Y, Kikushima H, Umino K, Kurosawa H, Furukawa T, Nihei $K$, Inoue $T$, Sano A, Komure $O$, Takahashi M, Yoshizawa T, Kanazawa I, Yamada M (1994): Dentatorubral and pallidoluysian atrophy expansion of an unstable CAG trinucleotide on chromosome 12p. Nature Genet 6: 14-18

Ohya K, Tachi N, Chiba S, Satoh T, Kon S, Kikuchi K, Imamura S, Yamagata H, Miki T (1994): Congenital myotonic dystrophy transmitted from an asymptomatic father with a DM-specific gene. Neurology 44: 1958-1960

Orr HT, Chung M-y, Banfi S, Kwiatkowski TJ Jr, Servadio A, Beaudet AL, McCall AE, Duvick LA, Ranum LPW, Zoghbi HY (1993): Expansion of an unstable trinucleotide CAG repeat in spinocerebellar ataxia type 1. Nature Genet 4: 221-226

Sambrook J, Fritsch EF, Maniatis T (1989): Molecular cloning-a laboratory manual. Cold Spring Harbor Laboratory Press, New York

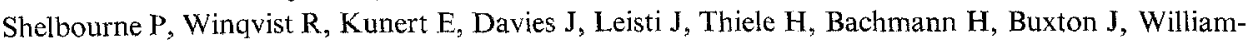
son B, Johnson K (1992): Unstable DNA may be responsible for the incomplete penetrance of the myotonic dystrophy phenotype. Hum Mol Genet 1(7): 467-473

The Funtington's disease collaborative research group (1993): A novel gene containing a trinucleotide repeat that is expanded and unstable on Huntington's disease chromosomes. Cell 72: $971-983$

Thornton CA, Johnson K, Moxley RT III (1994): Myotonic dystrophy patients have larger CTG expansions in skeletal muscle than in leukocytes. Ann Neurol 35: 104-107

Verkerk AJHM, Pieretti M, Sutcliffe JS, Fu Y-H, Kuhl DPA, Puzzuti A, Reiner O, Richards S, Victoria MF, Zhang F, Eussen BE, van Ommen G-JB, Blonden LAJ, Riggins GJ, Chastain JL, Kunst CB, Galjaard H, Caskey CT, Nelson DL, Oostra BA, Warren ST (1991): Identification of a gene (FMR-1) containing a CGG repeat coincident a breakpoint cluster region exhibiting length variation in Fragile $X$ syndrome. Cell 65: 905 -914 